\title{
INFRA-SUPRA STRUCTURE RELATIONS OF A MICROCLINE-GRANITE DOME IN THE SOMERO AREA, SVECOFENNIDES, SW FINLAND
}

\author{
H. STEL, R. VEENHOF, J. M. HUIZENGA, M. TIMMERMAN and J. M. H. HARTSINK
}

STEL, H., VEENHOF, R., HUIZENGA, J. M., TIMMERMAN, M. and HARTSINK, J. M. H., 1989: Infra-supra structure relations of a microcline-granite dome in the Somero area, Svecofennides, SW Finland. Bull. Geol. Soc. Finland 61, Part $2,131-134$.

Internal structure and deformational history of two granite domains with markedly distinct tectono-metamorphic evolutions occur in the Somero area, SW Finland. The Ruostejärvi dome, located NW of Somero, is characterized by a gently dipping core-mantle contact. The grade of metamorphism in this dome increases towards the core and migmatites have the character of injection veins. In contrast, in the Halkjärvi domain (SW of Somero) all structural elements are (sub)vertical and the rocks are of high metamorphic grade over the entire domain. In this case, migmatization resulted from in situ melt generation. The two domains are separated by a WNW-ESE striking lineament. This lineament represents a zone of intense shearing that caused an upward block movement of the southern domain. The Halkjärvi domain represents the infra-structure, while in the Ruostejärvi domain a supra structure of a granite dome is exposed. The variation in supra-infra structure is discussed in relation to the mechanism of diapirism in granite domes.

Key words: granites, domes, structural analysis, metamorphism, deformation, Proterozoic, Somero, Finland.

H. Stel, R. Veenhof, J. M. Huizenga, M. Timmerman and J. M. H. Hartsink: Institute of Earth Sciences, Free University, de Boelelaan 1085, 1081 HV Amsterdam, the Netherlands.

\section{Introduction}

The structure of the Svecofennides of SW Finland is dominated by megascopic granite bodies that enclose gneiss and schist belts (Fig. 1). The gneiss and schist belts are built-up of early orogenic intrusives (gabbro, tonalite) and cogenetic meta-volcanics and metasediments with an age of 1900-1880 Ma (Simonen 1980; Huhma 1986; Gaal and Gorbatschev 1987). The complex is thought to represent an ancient island arc (Simonen 1980). The rocks are strongly deformed, and metamorphosed up to high amphibolite, and locally granulite facies. Microcline-granite was generated in a late orogenic stage (Front and Nurmi 1987) and has an age of 1830-1810 Ma (Nurmi and Haapala 1986).

The present paper describes two granite domains which are separated by a lineament in the Somero area (Fig. 1). The area is located NW of the Kemiö-Orijärvi-Järvenpää-Lohja gneiss and schist belt (KOJL belt). The structure of the KOJL belt has been studied in detail by Tuominen 1957; Parras 1958; Verhoef and Dietvorst 1980; van Staal and Williams 1983; Bleeker and Westra 1987; Schreurs and Westra 1986. Simonen (1955) elaborated a geological map of the Somero area (Map sheet 2024) that served as 


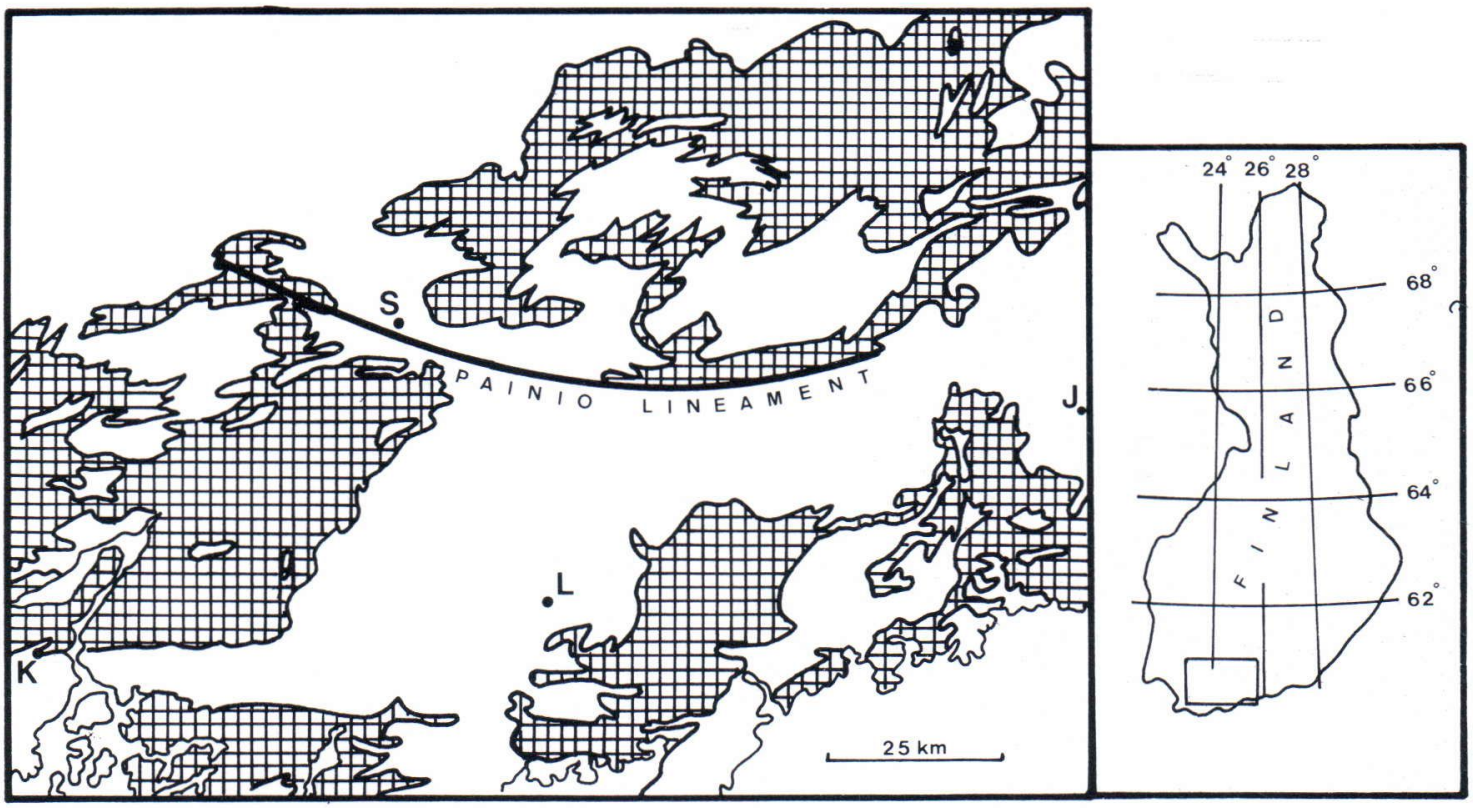

Fig. 1. Overview of Geology of SW Finland (after Schreurs and Westra, 1986). Late-tectonic microcline granite bodies are shown cross-hatched. S: Somero; K: Kemiö; O: Orijärvi, L: Lohja; J: Järvenpää. Inset: location of the map.

the basis of the present work. One of the most striking structural features in this area is the "palm-tree» like outcrop pattern of the supracrustal rock units that separate two granite domains (Fig. 1). The present contribution gives a structural analysis, presented in geometrical models, a comparison with the geology of the KOJL belt and a discussion on the origin of granite domes.

\section{Petrography}

Supra-crustal (mica, hornblende and quartzfeldspar schists) and early infra-crustal rocks (metagabbros, tonalites) are found in narrow belts or as mega-xenoliths in microcline granites. The geographical distribution of the rock units is shown on Fig. 2.

A brief characterization of the rocks is given below. Locations of characteristic outcrops are given by bracketed coordinates that refer to the grid of the Finnish geographical map.
Micaschists [2481.7, 6723.5] are composed of quartz, biotite, cordierite and garnet. Intercalated quartzitic beds and lenses are interpreted as bedding relicts. Cordierite porphyroblasts are commonly concentrated in bands parallel to the bedding. Mica-schists grade into quartz-feldsparmicaschists [2480.8, 6726.0]: fine grained felsic rocks composed of K-feldspar, plagioclase, quartz and biotite. Quartzitic lenses occur as a relict of sedimentary bedding. These rocks are interpreted as metamorphosed arkoses mixed with argillaceous material (cf. Simonen 1953). Two types of amphibolites are distinguished: hornblende schist and hornblende gneiss. The rocktypes may occur in one outcrop, e.g. [2477.8, 6725.7). Hornblende schists demonstrate sedimentary structures such as cross-bedding and grading, and have transitional relationships with micaschists. They are interpreted as resedimented volcanic deposits. In hornblende gneisses no primary structures were recognized. The rocks are characterized by a gneissic layering on a centimeter scale, and are well lineated. The origin 


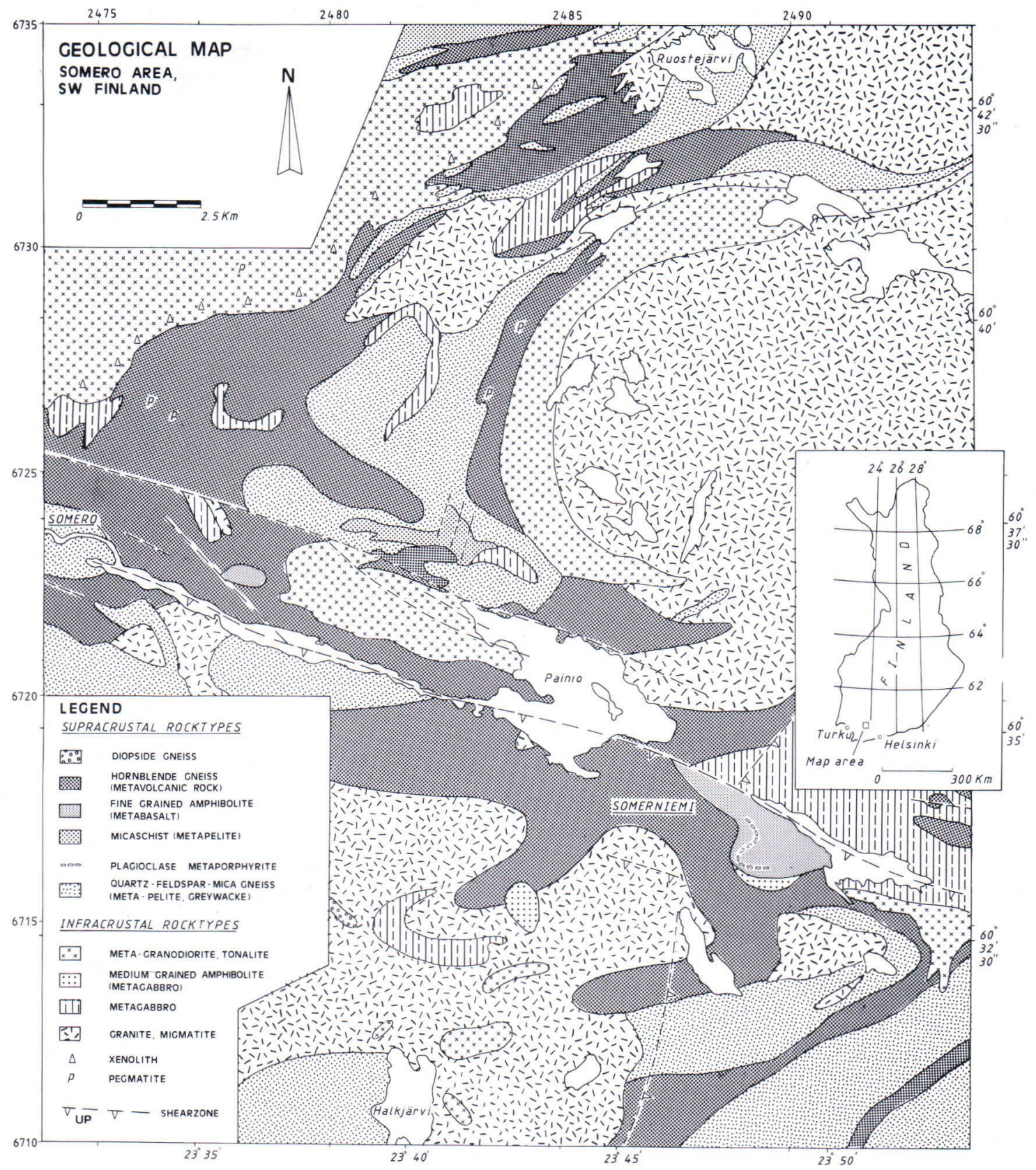

Fig. 2. Geological map of the Somero area.

of this rocktype is not known. Tonalite [2484.7, $6724.4]$ and gabbro [2477.4, 6727.8] occur as sills as well as discordant dikes. A foliation is defined by alignment of mica and hornblende; locally, an amphibole lineation is found. Xenolith-rich zones are found at the contact of tonalites and country rock. Migmatites occur abundantly in the area. Paleosomes and neosomes can vary in 


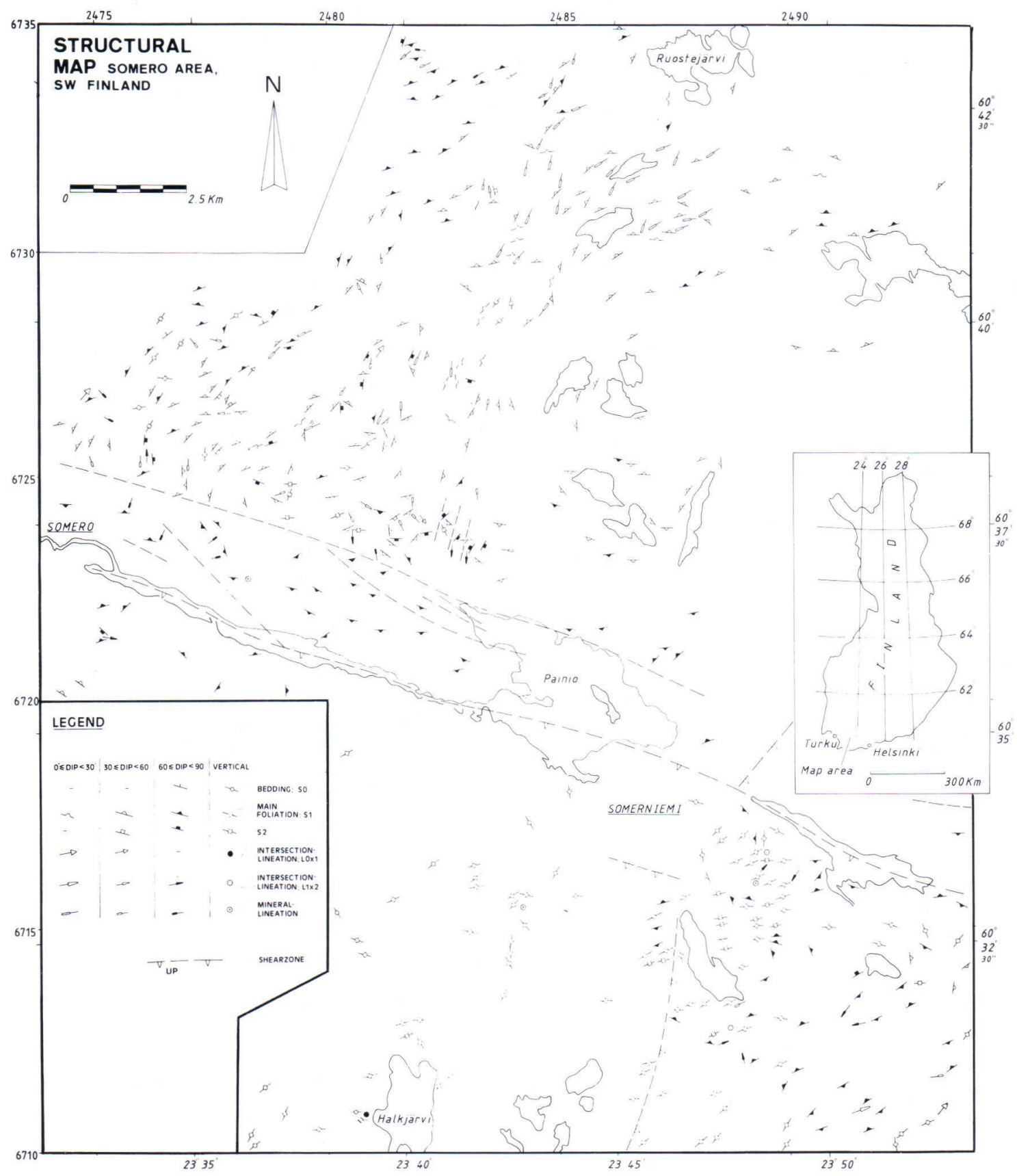

Fig. 3. Structural map of the Somero area.

width from a few centimeters to several meters. Two types of migmatite are distinguished. One type has injection vein-like leucosomes that cross- cut unaltered country rock (metasediments, metagabbro, tonalite) [2474.7, 6726.5]. The other type has leucosomes which are associated with 




Fig. 4. Form surface map of the Somero-area, showing the grace of $S_{1}$. Note the local deviation from the trend of $S_{0}$ on the geological map (Fig. 2).

metamorphic reaction rims in the country rock tite to granite. Mylonites and cataclasites are $[2483.5,6714.0]$ and are parallel to $S_{1}$. There is found in a WNW-ESE trending lineament in the a gradual transition from both types of migma- central part the area. 


\section{Structure}

Three structural domains are distinguished in the Somero area: the Ruostejärvi domain NE of Somero, the Halkjärvi domain S of Somero, and the Painio domain that encloses lineaments (Fig. 3). The domains differ in structure, and in the metamorphic evolution of the rocks. Three fold generations are recognized in the Ruostejärvi and Halkjärvi domains, labeled $\mathrm{F}_{1-3}$. Folds are overprinted by zones of mylonite and cataclasite, predominantly occurring in the Painio domain. We have carried out a structural analysis of the fold domains which is based on orientationvariation and overprinting relations of the following mesoscopic structural elements:

$\mathrm{S}_{0}$, sedimentary bedding, locally in metasediments.

$\mathrm{S}_{1}$, schistosity defined by alignment of biotite and amphibole, defining an axial plane cleavage in rootless $F_{1}$ isoclinal folds.

$\mathrm{S}_{2}$, crenulation cleavage, axial plane foliation of $\mathrm{F}_{2}$ folds.

$\mathrm{F}_{1}$, rootless, isoclinal folds with $\mathrm{S}_{1}$ as axial plane foliation.

$F_{2}$, open-tight meso- and macroscopic folds of $\mathrm{S}_{1}$.

$\mathrm{F}_{3}$, open, macroscopic folds.

$\mathrm{L}_{0^{*} 1}$, intersection lineation of $\mathrm{S}_{0}$ and $\mathrm{S}_{1}$.

$\mathrm{L}_{1 * 2}$, intersection lineation of the $\mathrm{S}_{1}$ and $\mathrm{S}_{2}$.

$\mathrm{L}_{\text {min }}$, mineral lineation, defined by alignment of amphibole and mica. $\mathrm{L}_{\min }$ is parallel to the $\mathrm{X}$ axis of deformed pebbles and xenoliths.

The structural map (Fig. 3) shows the orientation variation of the elements over the area. A 2D structural interpretation is presented by a form surface map (Fig. 4). This map demonstrates the trend of the main foliation, i.e. $\mathrm{S}_{1}$, and deviates markedly from that of $\mathrm{S}_{0}$ (represented by the geological map).

The Ruostejärvi domain is dominated by a gentle upright $\mathrm{F}_{3}$ antiform, with a $\mathrm{W}$ plunging axis. This antiform refolds older structures. There is a large angular relation between the $F_{3}$ axis on the one hand, and the $F_{1}$ and $F_{2}$ axes on the other hand. As a result, a highly a-cylindrical fold pattern is found in the hinge region of the $\mathrm{F}_{3}$ antiform. A 3D structural interpretation of this region is given in Fig. 5. Only very locally, small-scale $\mathrm{F}_{3}$ folds are found outside the antiformal hinge realm. Limbs of the antiform merely demonstrate a $F_{1}-F_{2}$ interference pattern on mesocopic scale. As a consequence, the fold pattern in the limb regions is cylindrical. Transition of a-cylindrical hinge to cylindrical limb realm is illustrated in Fig. 6. The complex, large scale $F_{1}, F_{2}$ and $F_{3}$ fold interference (Fig. 6) caused the typical palm-tree outcrop pattern of the metasediments (Fig. 1).

The structure of the Halkjärvi domain is dominated by vertical $F_{2}$ folds. Only very locally [2492.5, 6711.3], mesoscopic $F_{3}$ folds with subhorizontal NW-SE trending axes are found. Orientation of $\mathrm{F}_{2}$ foldaxes and axial surfaces are similar to those in the south-western part of the Ruostejärvi domain (E of lake Painio).

The Painio lineament consists of the narrow zones in which protomylonites, ultramylonites, cataclasites and pseudo-tachylites are found. These structures overprint $\mathrm{S}_{1}$ and $\mathrm{S}_{2}$. On Landsat images, the lineament is continuous over a length of $100 \mathrm{~km}$ (cf. Fig. 1). Two foliations are found in protomylonites. One foliation is a spaced banding defined by narrow zones $(1 \mathrm{~mm}$ in width) consisting of finely grained minerals (Fig. 7), predominantly quartz, white mica and epidote. This foliation strikes E-W and is (sub)vertical. Vertical slickenside striae occur on this cleavage plane. Another foliation is defined by the shape fabric of the minerals in the bulk rock. Longests axes of the minerals are oriented at $30-45^{\circ}$ to the spaced banding (Fig. 7). Ultra mylonites are found in the central parts of the lineaments. These rocks are extremely fine grained, and consist of partly sericitized plagioclase clasts, quartz, white mica, chlorite, epidote and opaques. In some cases a lamination is present, defined by an alternation of haematite and epidote rich bands. A pervasive foliation is defined by alignment of mica-aggregates and 


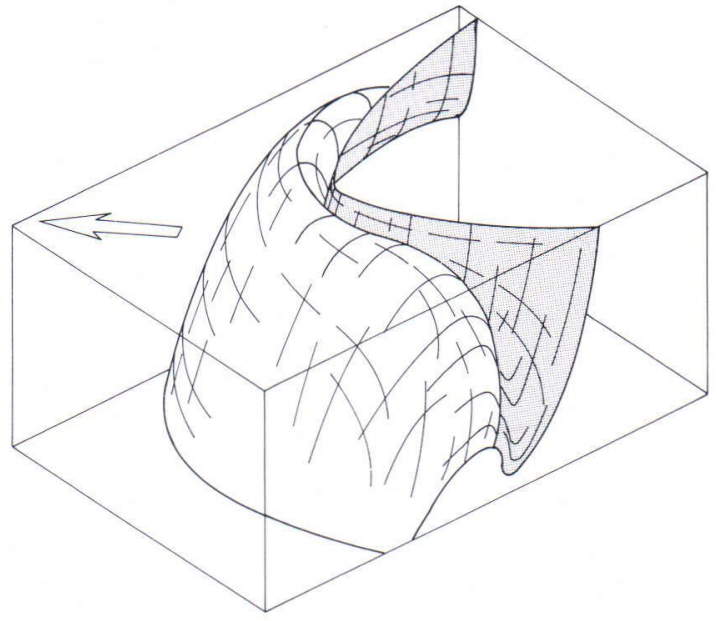

Fig. 5. Block-diagram of the central and northern part of the Ruostejärvi domain, looking in a NNE direction. $\mathrm{F}_{2}$ fold is refolded by macroscopic $\mathrm{F}_{3}$ antiform.

elongate domains of recrystallized quartz grains. This foliation is wrapped around feldspar clasts. The lamination and foliation are vertical and no lineation was found. Locally, micro-faults disrupt the lamination and the rocks are gradational to cataclasites.

\section{Metamorphism}

The metamorphic evolution of rocks is distinct in the Ruostejärvi and Halkjärvi domes. In general, metamorphic grade in the Halkjärvi domain is higher, and a distinct type of migmatite is found.

\section{Ruostejärvi domain}

An increase in metamoprhic grade of the rocks from West to East in the Ruostejärvi domain can be deduced from mineral assemblages. Amphibolites in the W contain blue-green hornblende, cummingtonite, albite and epidote. Intercalated micaschists contain garnet, biotite and oligoclase blasts. These mineral assemblages are typical for lower amphibolite facies (Myiashiro

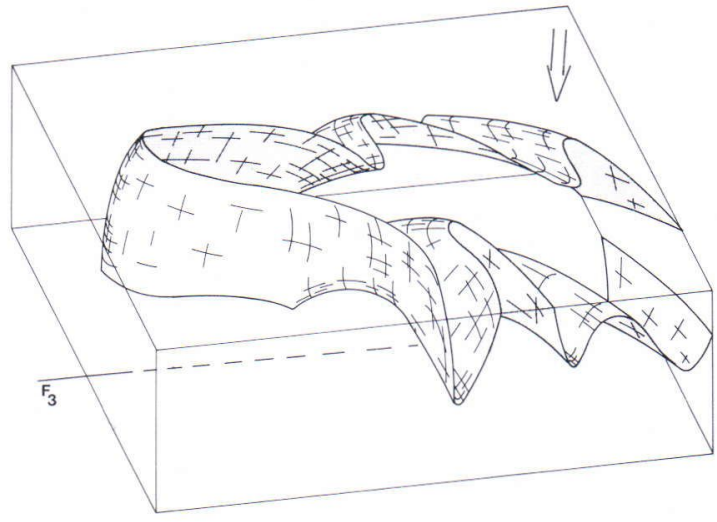

Fig. 6. Block-diagram of the central and southern part of the Ruostejärvi area, looking in a SW direction. In the southern part, an interference pattern of $F_{1}$ and $F_{2}$ (coaxial) is found; in the central part refolding by $F_{3}$ occurs.

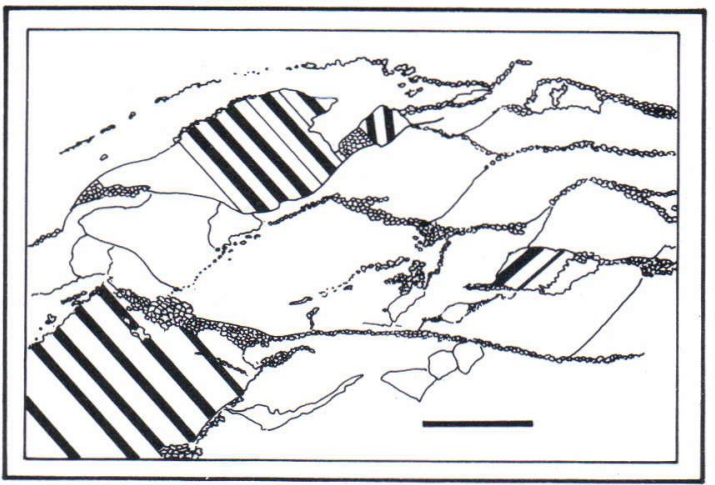

Fig. 7. Line drawing of micrograph of c-s mylonite from Painio lineament. Composite foliation of continuous s-surfaces and discontinuous c surfaces. See text for explanation scale bar: $0.5 \mathrm{~cm}$.

1974). High amphibolite facies conditions are characteristic for the core of the Ruostejärvi antiform. Clinopyroxene is found in metabasites, while cordierite is the dominant porphyroblast in micaschists. Cordierite blasts are in contact with $\mathrm{K}$-feldspar, both these minerals have inclusions of sillimanite needles and biotite, suggesting reaction (1) (Holdaway and Lee 1977): 


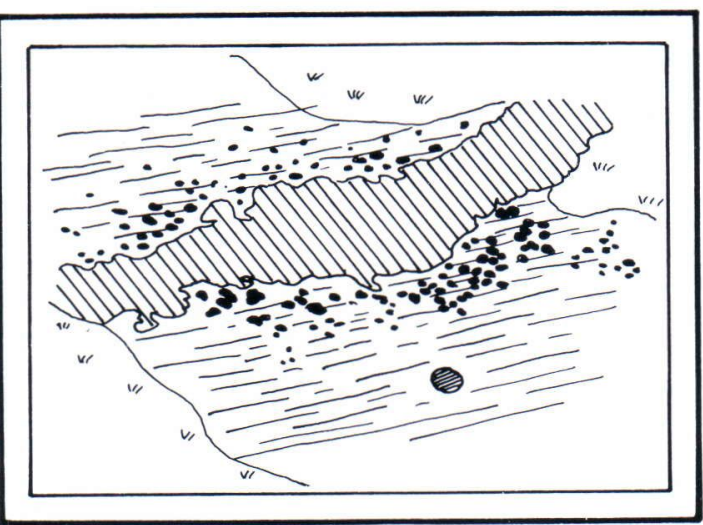

Fig. 8. Line drawing of photograph from outcrop near Halkjärvi, showing relation of garnet-occurrence (black spots) in schist and leucosomes of migmatite (vertically hatched). Scale bar (lense protector, $5 \mathrm{~cm}$.).

sill $+2 \mathrm{bi}+\mathrm{qtz}+\mathrm{CO}_{2}$

$=3 \mathrm{crd}+\mathrm{Kfsp}+\mathrm{H}_{2} \mathrm{O}$

Reaction (1) represents the peak of metamorphism, suggesting middle amphibolite facies conditions. Migmatites occur in the core of the regional $\mathrm{F}_{3}$ antiform. In this domain, leucosomes have the character of granitic-pegmatitic injection veins, with absence of reaction rims country rock.

\section{Halkjärvi dome}

Meta-pelites in the Halkjärvi dome are nearly completely migmatized. Only a few patches remained in which microstructures suggest a prograde metamorphic evolution that partly is similar to that of the Ruostejärvi dome. Locally however, garnet and cordierite are found in contact with each other, suggesting reaction (2) (Winkler 1979):

crd + bi + qtz $=$ gt $+\mathrm{Kfsp}+\mathrm{V}$

Migmatization in this domain appears to be related to garnet growth in melanosomes. This mineral occurs concentrated in bands at melanosome- leucosome boundaries (Fig. 8). This suggests a simultaneous formation of garnet and melt by reaction (3) (Grant 1985):

$\mathrm{qtz}+$ sill + bio $=\mathrm{Kfsp}+\mathrm{grt}+\mathrm{L}$

Reactions (2) and (3) indicate high grade metamorphic conditions (Winkler 1979).

A pervasive retrograde metamorphism affected the metapelites of the Ruostejärvi domain. Cordierite blasts in micaschists are partly replaced by andalusite, and some are overgrown by randomly oriented coarse grained white mica flakes.

In the Painio fault zone further retrograde metamorphism took place. In protomylonites overgrowth of plagioclase to muscovite and epidote is found, typical of greenschist facies conditions. Ultra-mylonites and cataclasites have syntectonic prehnite and pumpellyite veins, suggesting low grade metamorphic conditions.

\section{Relation deformation metamorphism}

\section{Ruostejärvi domain}

Biotite constitutes the $\mathrm{S}_{1}$ schistosity, its growth is pre-syn $\mathrm{F}_{1}$. Cordierite and $\mathrm{K}$-feldspar overgrow $S_{1}$ and at the rims of these minerals $S_{2}$ crenulations are included. This microstructure indicates a post $F_{1}$ to syn- $F_{2}$ growth. Migmatization probably post-dated $\mathrm{F}_{2}$, as micaschist inclusions in granitic veins contain an $\mathrm{S}_{2}$ crenulation cleavage. Migmatite veins are folded by $\mathrm{F}_{3}$, the constituting minerals, however, are nondeformed, and no deformation foliation was found. We propose that $F_{3}$ folding was syngenetic with the migmatization.

\section{Halkjärvi domain}

In the Halkjärvi domain migmatite veins are folded by $\mathrm{F}_{2}$. Garnet and cordierite growth are related to migmatization (see section above), hence they date syn-post $F_{2}$. 


\section{Interpretation}

For an interpretation of the tectono-metamorphic history of the area, it is convenient first to establish the effects of the latests deformation phase, i.e. mylonite formation under retrograde metamorphic conditions along the Painio lineament. Subsequently, we discuss earlier deformation phases.

\section{Painio lineament}

The structure of the protomylonites is similar to that of S-C mylonites (Berthé et al. 1979). In this interpretation, a continuous anisotropy (csurfaces) is aligned to the shear zone boundary (slip plane), while the discontinuous foliation (ssurfaces) initially is oriented at an angle of $45^{\circ}$ to the slip direction and curves into the s-surfaces. The proto-mylonites are interpreted accordingly. The vertical c-foliation marks a vertical shear plane. Angular relation of $c$ and s planes indicate an anti-clock wise sense of shear looking E, with a vertical shear direction, i.e. parallel to the slickenside striae. We interpret laminated mylonites as ultra-mylonites which formed at low grade metamorphic conditions. The deformation along the lineament resulted in an upward blockmovement of the Halkjärvi domain relative to the Ruostejärvi domain.

\section{Ruostejärvi and Halkjärvi domains}

Structural style and metamorphic evolution in the Ruostejärvi domain are distinct from that in the Halkjärvi domain. In the former, an increasing grade of metamorphism from low to high amphibolite facies is deduced. Rocks of the Halkjärvi domain on the other hand are all migmatic and of high metamorphic grade. The nature of the migmatites in the two domains differs markedly. In the Ruostejärvi domain leucosomes are pegmatitic injection veins. In the Halkjärvi domain strong interaction of leucosomes and country rock took place, suggesting in situ melt generation. The time relation of migmatite formation and deformation is also distinct; in the Ruostejärvi domain, migmatic veins cut through $\mathrm{F}_{2}$ folds, while in the Halkjärvi domain they are folded by $\mathrm{F}_{2}$.

We propose that the Halkjärvi domain represents a deeper erosion level than the Ruostejärvi domain. Both the movement sense along the Painio lineament and the metamorphic evolution in the two domains support this interpretation. The correlation of the deformation structures in both the domains is problematic, due to the presence of the tectonic discontinuity in the Painio domain. However, style of $\mathrm{F}_{2}$ folds in both the domains is comparable. Moreover, in the southern part of the Ruostejärvi domain, orientation of fold axes and axial planes gradually change towards parallellism with $\mathrm{F}_{2}$ folds in the Halkjärvi domain (Fig. 6). These relations allow correlation of $\mathrm{F}_{2}$ folds over the Painio lineament. It is suggested that the Halkjärvi domain represents the deep crustal continuation of the Ruostejärvi domain.

\section{Discussion}

Discussions on the genesis of granite domes focus on the problem of the relative importance of diapirism (Griffin 1979; van Staal and Williams 1983; Front and Nurmi 1987; Bleeker and Westra 1987). Several diagnostic criteria for this process have been proposed (Dixon 1974; Bateman 1984; van den Eeckhout 1986). However, it is difficult to apply such criteria to the Finnish setting. One of the major problems is the outcrop level of the macroscopic structures. While vertical dimensions of structures may reach several kilometers, the topography shows relief in the order of tens of meters, so a direct comparison of supra- and infrastructure of granite domes is impossible. In this respect, the Somero-area can be of great interest because two different levels in a granite body are exposed. The lower level (Halkjärvi domain) is characterized by a high grade of 
metamorphism and migmatites that derived from in situ-melt generation that took place at a relatively early stage in the deformation history $\left(\mathrm{F}_{2}\right)$. The higher level (Ruostejärvi dome) is characterized by a gently plunging antiform and shows an injection-type of migmatization that occurred later in the deformation history $\left(\mathrm{F}_{3}\right)$. The geometry of the structure is comparable with predictions of theoretical models of a diapiric structure (Dixon 1976). The combination of steep infrastructure with in situ-melt generation and flat lying supra-structure dominated by injection veins matches well with a model of »ballooning diapirs» such as proposed by Bateman (1984). This author proposes a scenario of diapirism that involves generation of partial melt in a deep crustal level, diffusion through a vertical fabric and ballooning by injection at a high level.

In order to test this hypothesis, current research focuses on a detailed strain analysis of this area.

\section{Correlation with other areas}

The tectono-metamorphic evolution of metasedimentary rocks in the granite domains appears to be similar to that in the KOJL belt (cf. Bleeker and Westra 1987). A striking difference is the orientation of the folds in the two settings. In the KOJL belt syn-migmatization folds $\left(\mathrm{F}_{2}\right)$ have E-W oriented fold axes, while post migmatization folds $\left(\mathrm{F}_{3}\right)$ have NNE-SSW oriented axes. In the Ruostejärvi domain syn-migmatization folds are $\mathrm{F}_{3}$ structures, while post-migmatization structures with NNE-SSW trending axes are lacking. At present, a satisfactory explanation for this divergency is lacking.

\section{Conclusions}

Three structural domains are distinguished in the Somero area:

1) The Ruostejärvi domain, in which an acylindrical fold-interference pattern of $F_{1}+F_{2}$ and $F_{3}$ is found.

2) The Halkjärvi domain in which $F_{1,2}$ and $F_{3}$ are vertical, resulting a cylindrical fold-interference pattern.

3) The Painio lineament in which mylonites are found and along which the Halkjärvi domain underwent an upward block-movement. Metamorphic conditions of the rocks in the Halkjärvi domain are higher, and this domain represents a deep crustal level and infra-structure of a granite dome. A supra-structure of a granite dome is exposed in the Ruostejärvi domain. The relation of infra and supra-structures does not contradict a diapiric origin of granite domes, but the evidence is not conclusive.

Acknowledgements. We thank drs. H. Jelsma, R. Konert and P. Reemst for providing field data. Drs. H. Helmers and Dr. L. Westra are thanked for stimulating discussions.

Prof. Dr. S. Cloetingh suggested improvements of the manuscript. Two anonymous reviewers are thanked for suggestions.

\section{References}

Bateman, R. J., 1984. On the role of diapirism in the segregation, ascent and final emplacement of granitoid magmas. Tectonophysics 110, 211-231.

Berthé, D.; Choukroune, P. \& Jegouzo, P., 1979. Orthogneiss, mylonite and non-coaxial deformation of granites: the example of the South Armorican shear zone. J. Struct. Geol. 1, 31-42.

Bleeker, W. \& Westra, L., 1987. The evolution of the Mustio

gneiss dome. Svecofennides of SW Finland. Precambrian Res. 36, 227-240.

Dixon, J. M., 1975. Finite strain and progressive deformation in models of diapiric structures. Tectonophysics 28 , $89-124$.

Eeckhout van den, B., 1986. A case study of a mantled gneiss antiform, the Hospitalet Massif, Pyrenees (Andorra, France). Geologica Ultraiectina 45. 
Front, K. \& Nurmi, P. A., 1987. Characteristics and geological setting of syn-kinematic Sveco-karelian granitoids in southern Finland. Precambrian Res. 35, 207-224.

Gaal, G. \& Gorbatschev, R., 1987. An outline of the Precambrian evolution of the Baltic shield. Precambrian Res. 35, $15-52$.

Grant, J. A., 1985. Phase equilibra in low pressure partial melting of pelitic rocks. Am. J. Sci. 285, 409-435.

Griffin, V. S., 1979. Diapirism, polydeformation and amoebidal tectonic patterns in the Svecofennidic area of southwestern Finland. Tutkimusraportti Geol. Surv. Finl. $41,16 \mathrm{pp}$.

Hobbs, B. E.; Means, W. D. \& Williams P. F., 1976. An Outline of Structural Geology. Wiley, New York, 571 pp.

Holdaway, M. J. \& Lee, S. L., 1977. Fe-Mg cordierite stability in high grade pelitic rocks based on experimental, theoretical and natural observations. Contrib. Mineral. Petrol. 63, 175-198.

Huhma, H., 1986. Sm-Nd, U-Pb and $\mathrm{Pb}-\mathrm{Pb}$ isotopic evidence for the origin of the early Proterozoic crust in Finland. Geol. Surv. Finland, Bull. 337, 48 p.

Miyashiro, A., 1974. Metamorphism and metamorphic belts. Wiley, New York.

Nurmi, P. A. \& Haapala, I., 1986. The Proterozoic granitoids of Finland: granite types, metallogeny and relation to crustal evolution. Bull. Geol. Soc. Finland 58, 203-233.

Parras, K., 1958. On the charnokites in the light of a highly metamorphic rock complex in southwestern Finland. Bull. Comm. Geol. Finlande 181, 1-137.

Schreurs, J. \& Westra, L., 1986. The thermotectonic evolution of a Proterozoic, low pressure granulite dome, West Uusimaa, SW Finland. Contrib. Mineral. Petrol. 93, $236-250$.

Simonen, A., 1953. Stratigraphy and sedimentation of the Svecofennidic, early Archean supracrustal rocks in southwestern Finland. Bull. Comm. Geol. Finlande 160.

—, 1955. Geological map of Finland 1: 100 000, Sheet 2024 Somero. Geol. Surv. Finland.

-, 1980. The Precambrian in Finland. Geol. Surv. Finland, Bull. 304, 58 pp.

Staal van, C. R. \& Williams, P. F., 1983. Evolution of a Svecofennian mantled gneiss domes in SW Finland, with evidence for thrusting. Precambrian Res. 21, 101-128.

Tuominen, H. V., 1957. The structure of an Archean are Orijärvi, Finland. Bull. Comm. Geol. Finlande, 177, 32 pp.

Verhoef, P. N. W. \& Dietvorst, E. J. L., 1980. Structural analysis of differentiated schists and gneisses in the Taalintehdas area, Kemiö Island, Southwest Finland. Bull. Geol. Soc. Finland 52, 147-164.

Winkler, H. G. F., 1979. Petrogenesis of metamorphic rocks. Springer Verlag, New York, 348 pp.

Received June 23, 1989

Revision accepted November 3, 1989 